\title{
Heavy metal pollution in Ancient Nara, Japan, during the eighth century
}

\author{
Hodaka Kawahata ${ }^{1,2^{*}}$, Shusuke Yamashita ${ }^{2}$, Kyoko Yamaoka ${ }^{3}$, Takashi Okai ${ }^{3}$, Gen Shimoda ${ }^{3}$ and Noboru Imai ${ }^{3}$
}

\begin{abstract}
We quantitatively investigated the eighth century heavy metal pollution in Heijo-kyo (Ancient Nara), the first large, international city of Japan. In this metropolis, mercury, copper, and lead levels in soil were increased by urban activity and by the construction of the Great Buddha statue, Nara Daibutsu. Mercury and copper pollution associated with the construction of the statue was particularly high in the immediate vicinity of the statue, but markedly lower in the wider city environment. We therefore reject the hypothesis that extensive mercury pollution associated with the construction of the Nara Daibutsu made it necessary to abandon Ancient Nara, even though severe lead pollution was detected at several sites. The isotopic composition of the lead indicated that it originated mainly from the Naganobori mine in Yamaguchi, which was a major source of the copper for the Nara Daibutsu.
\end{abstract}

Keywords: $\mathrm{Hg}$; Cu and Pb pollution; Ancient urban activity; Heijo-Kyo (Ancient Nara); the Great Buddha (Nara Daibutsu); Eighth century

\section{Background}

Human civilizations are physical spheres of human activity on earth. This human activity is typically associated with pollution, which results in environments becoming dangerous to live in, or in which chemical substances or energy may become limited (Matsui 2007). Although pollution increased dramatically during the industrial revolution, the material cycle was also affected by ancient human activity, especially mining and smelting. For example, the rate of atmospheric $\mathrm{Pb}$ deposition in the Jura Mountains of Switzerland has been affected appreciably by human activity over the last 2,100 years, with rates of deposition during this period being at least 10 times that of the original natural flux (Shotyk et al. 1998). The establishment of large cities in ancient times would lead to chemical pollution, mainly due to their large populations and the commencement of the metalworking industries. However, the extent of these ancient episodes of pollution has not yet been quantified.

Heijo-kyo (Ancient Nara) was Japan's second capital and the first large and international city (from 710 to

\footnotetext{
*Correspondence: kawahata@aori.u-tokyo.ac.jp

'Atmosphere and Ocean Research Institute, The University of Tokyo,

Kashiwanoha 5-1-5, Kashiwa, Chiba 277-8564, Japan

${ }^{2}$ Department of Earth and Planetary Science, Faculty of Science, The University of Tokyo, Hongo 7-3-1, Bunkyo-ku, Tokyo 113-0033, Japan Full list of author information is available at the end of the article
}

784 A.D.). Although Fujiwara-kyo, the layout of which is based on the grid of a Chinese city, is officially considered to be Japan's first capital, it was a small city that only served as the capital for 6 years after construction was completed. Heijo-kyo is a registered UNESCO World Heritage site (http://whc.unesco.org/en/list/870) (Figure 1). It had a maximum population of 50,000 to 200,000, making it half the size of Constantinople (Istanbul) at that time (Japan Broadcasting Corporation 2012), and a high population density of 2,000 to 8,000 people $\mathrm{km}^{-2}$. The city covered approximately $25 \mathrm{~km}^{2}$ and had an irregular rectangular shape modeled after Chang'an, the capital city of Tang Dynasty China. Numerous foreign visitors traveled to Ancient Nara where they introduced their cultures. These visitors included traders and Buddhist monks from China, Korea, India, and Vietnam. Buddhism prospered and was particularly influential in politics where it was adopted by the government and propagated by foreign priests. As a result, the Tenpyo Culture was developed, a lowery culture strongly connected to Buddhism (UNESCO World Heritage site; Hall 1993). A number of great temples and religious structures were established during this time, one of which was Todaiji Temple, which is famous for its very large Buddha statue known in Japanese as the Nara Daibutsu. The Great Buddha of Nara is the world's largest gilt bronze statue of Buddha. The statue, which is 


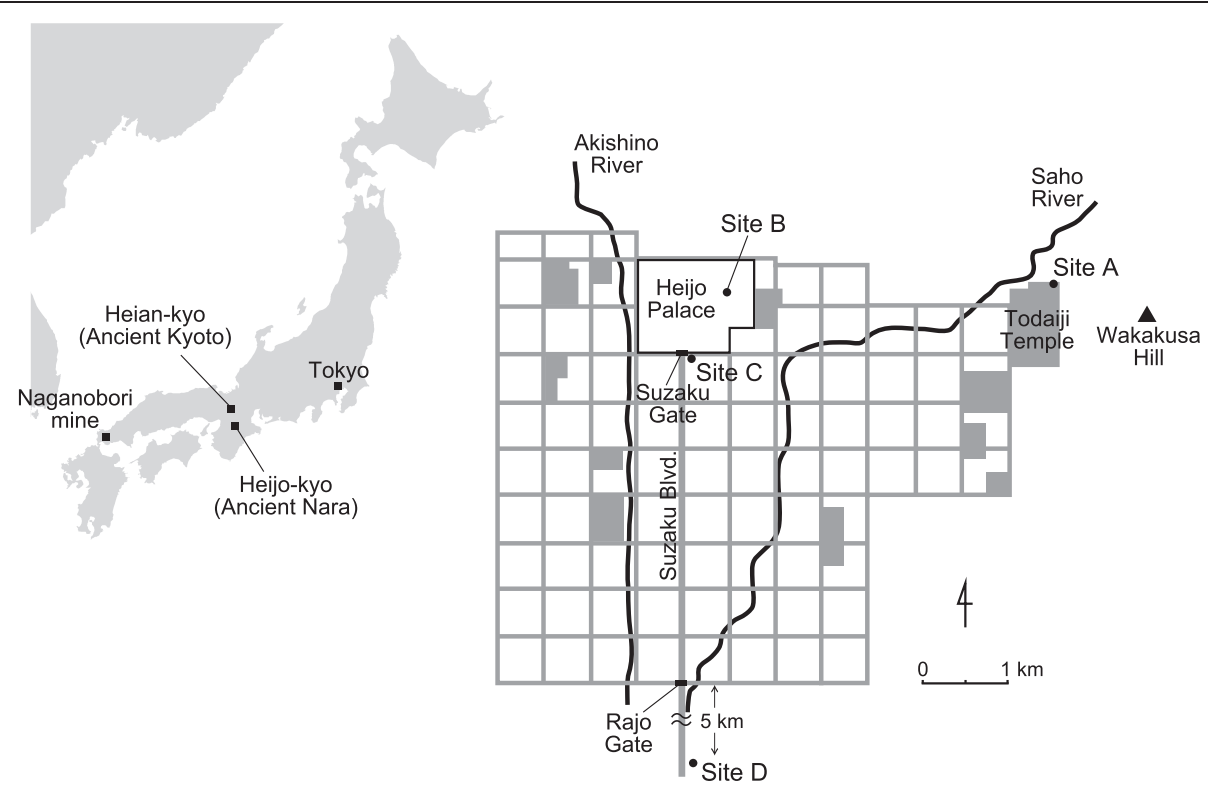

Figure 1 Location of Ancient Nara in Japan, with inset showing soil sampling sites and other relevant locations in and around the city. The streets of Ancient Nara had ditches on both sides. These ditches functioned as drains or sewers, carrying polluted water into the main rivers. People may have indiscriminately disposed of waste materials in such ditches, occasionally even human skulls.

approximately $15 \mathrm{~m}$ tall and is seated in a cross-legged position (Figure 2), was built in response to repeated outbreaks of smallpox in Japan in the 730 s A.D. (Hall 1993). The statue was constructed in the following stages: (1) A rough framework was constructed from wood and other materials and then covered with micaceous clay, from which the features of the statue were sculpted. (2) After the sculpted clay surface had dried, a mixture of sand and clay was laid over the clay form, baked, and removed in sections to serve as the outer mold. (3) After removal of the outer mold, the clay form was pared down so that it could serve as the inner mold. The completion of these three stages took almost 2 years. (4) The outer mold was reassembled around the inner mold and (5) smelted bronze was poured into the space between the two molds. Because the statue was so high, the last two stages were repeated eight times over the course of 4 years to complete the casting, starting from the bottom of the statue and working toward the top. (6) After the outer mold was removed, the surface of the statue was gilded by the amalgamation method. To make the amalgam, $\mathrm{Au}$ was dissolved in $\mathrm{Hg}$ at a ratio of about 1:5. After this fluid was applied to the statue, the surface was broiled to evaporate the $\mathrm{Hg}$, leaving a uniform layer of $\mathrm{Au}$ on the surface. Emperor Shomu issued an imperial decree to build the great statue of Buddha, intending to resolve the national crisis through Buddha's divine protection (Hall 1993). The hall of the Buddha was also

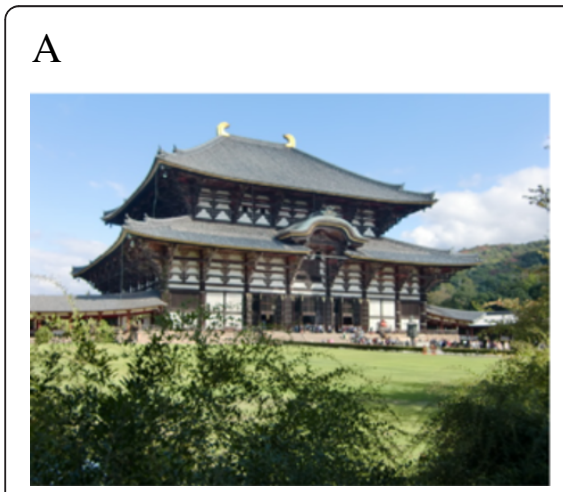

\section{B}

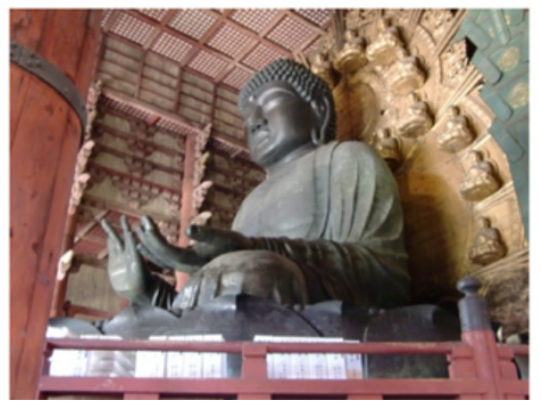

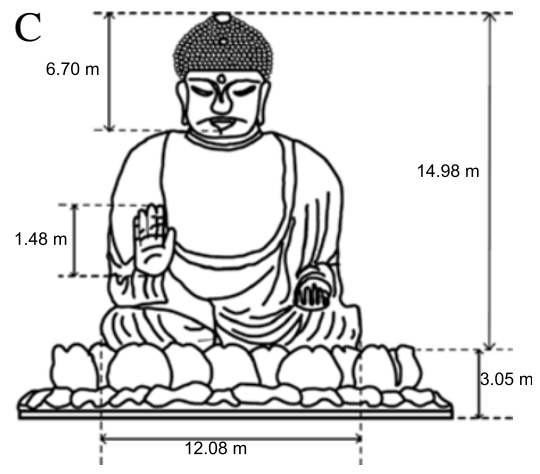

$\mathrm{C}$

Figure 2 Photographs and schematic representation of the Nara Daibutsu. (A) Current Great Buddha Hall (Daibutsuden), which is $57.5 \mathrm{~m}$ wide, $50.5 \mathrm{~m}$ deep, and $49.1 \mathrm{~m}$ tall. It was rebuilt in 1691 A.D. due to fire. The original hall was even larger and had a width of $86 \mathrm{~m}$. (B, C) Great Buddha. Processes involved in the production of the Buddha were as follows: More than 2 million people were reportedly involved in this project, even though the total population of Japan was 5 million at that time (Kito 2000). 
the largest ancient wooden structure in the world, although the 'Metropol Parasol' in Seville, Spain, is currently the largest such structure in the world (Moore 2011).

It has been considered that Ancient Nara may have been polluted by urban activity, particularly by activities associated with the construction of the Nara Daibutsu, which was made of $499,000 \mathrm{~kg}$ of $\mathrm{Cu}$ and $8,500 \mathrm{~kg}$ of $\mathrm{Sn}$ and gilded with $146 \mathrm{~kg}$ of $\mathrm{Au}$ and $820 \mathrm{~kg}$ of $\mathrm{Hg}$ (Konishi 2002). The statue was gilded by the amalgamation method, in which an amalgam of $\mathrm{Hg}$ and $\mathrm{Au}$ was applied to the surface and then heated to evaporate the Hg. Shirasuga (2002) hypothesized that the $\mathrm{Hg}$ that was released into the environment around Ancient Nara due to the construction of the Nara Daibutsu caused people in the area to suffer significantly from an unidentified 'strange disease' and that the government was forced to relocate to a new capital for fear of an evil curse or divine punishment. He also proposed that careless disposal of waste materials from the copper refining process was primarily responsible for a treeless, grass-covered hill located to the east of Todaiji Temple. Although these theories have little supporting historical or scientific evidence, they have nevertheless persisted in popular culture and are often cited in Japanese television programs on the Nara Daibutsu. Another explanation for the relocation of the capital city may have been because Emperor Kammu wished to relocate the capital to an area with better transportation routes, and/or to escape the power of the Buddhist clergy (Hall 1993).

Urban activity is known to pollute the environment on both local and regional scales, and in a city as large as Ancient Nara, people would have relied on the natural environment to dispose of their sewage and other waste. They may have buried their waste in large holes or in ditches, practices which may have led to the accumulation of waste and pollutants. In this study, we provide quantitative data for the presence of toxic heavy metals, such as $\mathrm{Hg}, \mathrm{Pb}, \mathrm{Cu}$, and $\mathrm{Fe}$, in ancient soil samples and remains collected from archeological sites in Ancient Nara. Furthermore, we evaluate the effect of urban activity on ancient metal pollution and discuss the environmental effects associated with the construction of the Nara Daibutsu.

\section{Case description}

\section{Background and climate of modern Nara}

The archeological site of Ancient Nara is located within the modern city of Nara, which is surrounded by mountains on three sides and is located at the northern end of the Nara Basin in the Kansai region of Japan (Figure 1). The dominant soils consist of terrace deposits, derived from metamorphic mudstone and biotite granite from the Saho River. Metal pollution has not been reported in this area in recent times as mining for metals is no longer conducted in the region (Ozaki 2000).
Nara has a mild climate, with mean temperatures ranging between $3.8^{\circ} \mathrm{C}$ (January) and $26.6^{\circ} \mathrm{C}$ (August). The mean annual rainfall is $1,333 \mathrm{~mm}$ and the direction of the prevailing winds is southeast in summer and northwest in winter (Nara Meteorological Observatory 2014).

\section{Sampling sites}

Ancient soil samples were carefully collected from four historic sites in and around Ancient Nara (Figure 1) under the supervision of archeologists (Table 1). The age of each sample was determined based on any artifacts that were present, from writings on mokkan (long, thin, narrow pieces of wood strung together that were used to write on in ancient times), and from other archeological evidence. The sampled soil sediments had not been disturbed and heavy metal contamination by subsequent overprinting is not suspected because Ancient Nara became an agricultural area after the capital moved to Kyoto, and the soil sediments remained deeply buried for more than 1,000 years (Hall 1993).

Site A is located $20 \mathrm{~m}$ north of a section of the hall that housed the Nara Daibutsu in Todaiji Temple in approximately 750 A.D. (Figure 3). Three kinds of samples were taken from a pit that was excavated for the construction of a drain pipe in October 2011. The samples were classified based on a description of the cross section of this section by the Buried Cultural Property Investigation Center (Figure 3; personal communication with Mr. M. Kanekata and Mr. T. Yasui; Board of Education of Nara City 2011). Sampling was supervised by Mr. Kanekata and Mr. Yasui (Board of Education of Nara City 2011). Sample 1 was dated to the middle of the Nara period (around 750 A.D.) on the basis of the presence of many copper particles originating from the bronze blast furnace used in the construction of the Nara Daibutsu (Ishino 2004). Therefore, sample 1 is assumed to represent direct metal contamination (Figure 3). Samples 2 and 3 were dated to the 12th and 16th centuries, respectively, because they contained debris and soils which corresponded to fires in 1180 and 1567 A.D. that destroyed the wooden structures housing the statue.

Site B was situated inside the central palace, the home of the imperial family and the location of the central governmental offices. Currently, excavations and investigations of this area are performed under the auspices of the Nara National Research Institute for Cultural Properties. These samples were collected from a dump in this area in order to estimate the pollution associated with garbage at the palace in the very center of Ancient Nara. The artifacts present in these samples were dated from the late eighth century (Nara National Research Institute for Cultural Properties 2010, 2012a).

Site $C$ was located in front of Suzaku-mon, the south main gate of the palace. Eighteen samples were collected 
Table 1 Soil metal concentrations and $\mathrm{Pb}$ isotopic ratios for samples from Ancient Nara and Naganobori mine

\begin{tabular}{|c|c|c|c|c|c|c|c|c|c|c|c|c|c|}
\hline Site & Sample & Age & Sample & $\mathrm{Hg} \mathrm{ppb}$ & Cu ppm & $\mathrm{Pb}$ ppm & Fe ppm & Mn ppm & Co ppm & Ni ppm & Zn ppm & ${ }^{208} \mathrm{~Pb} /{ }^{206} \mathrm{~Pb}$ & ${ }^{207} \mathrm{~Pb} /{ }^{206} \mathrm{~Pb}$ \\
\hline A & $\begin{array}{l}\text { Dark gray gravel } \\
\text { containing copper slag }\end{array}$ & Middle eighth century & $1-A$ & 92 & 370 & 100 & 34,000 & 170 & 21 & 14 & 60 & 2.094 & 0.850 \\
\hline A & $\begin{array}{l}\text { Dark gray gravel } \\
\text { containing copper slag }\end{array}$ & Middle eighth century & $1-B$ & 66 & 57 & 32 & 36,000 & 240 & 23 & 14 & 52 & & \\
\hline A & Dark gray clay & Twelfth century & 2 & 298 & 62 & 18 & 18,000 & 140 & 12 & N.D. & 26 & & \\
\hline A & Light orange-colored sand & Sixteenth century & 3 & 255 & 56 & 210 & 56,000 & 170 & 27 & 29 & 120 & & \\
\hline B & $\begin{array}{c}\text { Brownish soil containing } \\
\text { wood debris }\end{array}$ & Late eighth century & 100 & 229 & 18 & 90 & 24,000 & 550 & 17 & 11 & 47 & & \\
\hline B & $\begin{array}{l}\text { Dark gray soil containing } \\
\text { wood debris }\end{array}$ & Late eighth century & 106 & 207 & 8.6 & 130 & 14,000 & 95 & 9 & 3.3 & 30 & 2.093 & 0.851 \\
\hline B & $\begin{array}{l}\text { Dark gray soil containing } \\
\text { wood debris }\end{array}$ & Late eighth century & 118 & 133 & 12 & 16 & 15,000 & 98 & 7.8 & 3.5 & 28 & & \\
\hline C & River bed & $\begin{array}{l}\text { Just before the } \\
\text { eighth century }\end{array}$ & 203 & 45 & 5.6 & 200 & 5,800 & 92 & 5.2 & 4.1 & 23 & 2.093 & 0.851 \\
\hline C & $\begin{array}{c}\text { Soil preparation for } \\
\text { Heijo-kyo }\end{array}$ & $\begin{array}{l}\text { Early to middle } \\
\text { eighth century }\end{array}$ & 204 & 86 & 11 & 1,100 & 30,000 & 630 & 17 & 15 & 38 & 2.093 & 0.851 \\
\hline C & $\begin{array}{c}\text { Soil preparation for } \\
\text { Heijo-kyo }\end{array}$ & $\begin{array}{l}\text { Early to middle } \\
\text { eighth century }\end{array}$ & 205 & 78 & 4.8 & 470 & 12,000 & 520 & 9.4 & 9.4 & 27 & & \\
\hline C & $\begin{array}{c}\text { Muddy soil around pillar } \\
\text { hole }\end{array}$ & $\begin{array}{l}\text { Early to middle } \\
\text { eighth century }\end{array}$ & 206 & 92 & & & & & & & & & \\
\hline C & $\begin{array}{l}\text { Muddy soil around } \\
\text { pillar hole }\end{array}$ & $\begin{array}{l}\text { Early to middle eighth } \\
\text { century }\end{array}$ & 207 & 59 & 5.7 & 380 & 10,000 & 140 & 4.9 & 5.7 & 20 & & \\
\hline C & $\begin{array}{l}\text { Muddy soil burying } \\
\text { the well-frame }\end{array}$ & Eighth century & 201 & 107 & 4.6 & 500 & 8,200 & 150 & 6.3 & 5.1 & 25 & 2.093 & 0.851 \\
\hline C & $\begin{array}{l}\text { Muddy soil burying } \\
\text { the well-frame }\end{array}$ & Eighth century & 202 & 103 & 5.7 & 15 & 7,400 & 140 & 8.8 & 6.7 & 50 & & \\
\hline C & $\begin{array}{l}\text { Muddy soil in dump } \\
\text { site around smithy }\end{array}$ & Eighth century & 208 & 157 & 18 & 1,200 & 57,000 & 2,300 & 32 & 22 & 39 & 2.093 & 0.851 \\
\hline C & $\begin{array}{l}\text { Muddy soil in dump } \\
\text { site around smithy }\end{array}$ & Early ninth century & 209 & 155 & & & & & & & & & \\
\hline C & Muddy soil in paddy field & Medieval period & 210 & 212 & 9.3 & 18 & 24,000 & 200 & 7.2 & 6.5 & 26 & & \\
\hline C & Muddy soil & Age of 1870 to 1960 & 211 & 521 & 21 & 230 & 11,000 & 190 & 4.8 & 11 & 50 & & \\
\hline C & Muddy soil in pillar hole & $\begin{array}{l}\text { Early to middle } \\
\text { eighth century }\end{array}$ & 212 & 141 & & & & & & & & & \\
\hline C & Muddy soil in pillar hole & $\begin{array}{l}\text { Early to middle } \\
\text { eighth century }\end{array}$ & 213 & 165 & & & & & & & & & \\
\hline
\end{tabular}


Table 1 Soil metal concentrations and $\mathrm{Pb}$ isotopic ratios for samples from Ancient $\mathrm{Nara}$ and Naganobori mine (Continued)

\begin{tabular}{|c|c|c|c|c|c|c|c|c|c|c|c|c|c|}
\hline C & Muddy soil in pillar hole & $\begin{array}{l}\text { Early to middle } \\
\text { eighth century }\end{array}$ & 214 & 118 & & & & & & & & & \\
\hline C & Muddy soil in pillar hole & $\begin{array}{l}\text { Early to middle } \\
\text { eighth century }\end{array}$ & 215 & 104 & & & & & & & & & \\
\hline C & Muddy soil in pillar hole & $\begin{array}{l}\text { Early to middle } \\
\text { eighth century }\end{array}$ & 216 & 137 & & & & & & & & & \\
\hline C & Muddy soil in pillar hole & $\begin{array}{l}\text { Early to middle } \\
\text { eighth century }\end{array}$ & 217 & 106 & & & & & & & & & \\
\hline C & Muddy soil in paddy field & Medieval period & 218 & 185 & & & & & & & & & \\
\hline D & Brownish sandy soil & Late eighth century & 31 & 276 & 13 & 740 & 61,000 & 1,200 & 20 & 10 & 110 & & \\
\hline D & Dark gray silty soil & Middle eighth century & 34 & 298 & 14 & 880 & 55,000 & 730 & 24 & 13 & 140 & 2.093 & 0.851 \\
\hline D & Dark gray sandy soil & Very early eighth century & 38 & 39 & 2.3 & 13 & 21,000 & 320 & 14 & N.D. & 35 & & \\
\hline \multicolumn{14}{|c|}{ Naganobori mine } \\
\hline & Slag & 300,000 & 360 & 180,000 & 1,800 & 500 & 3.9 & 8,000 & 2.092 & 0.846 & & & \\
\hline & Slag & 110,000 & 62 & 210,000 & 1,100 & 81 & 1.2 & 1,400 & 2.092 & 0.847 & & & \\
\hline & Chrysocolla & 620,000 & 21 & 270 & 8.1 & N.D. & N.D. & 4,100 & 2.091 & 0.847 & & & \\
\hline
\end{tabular}




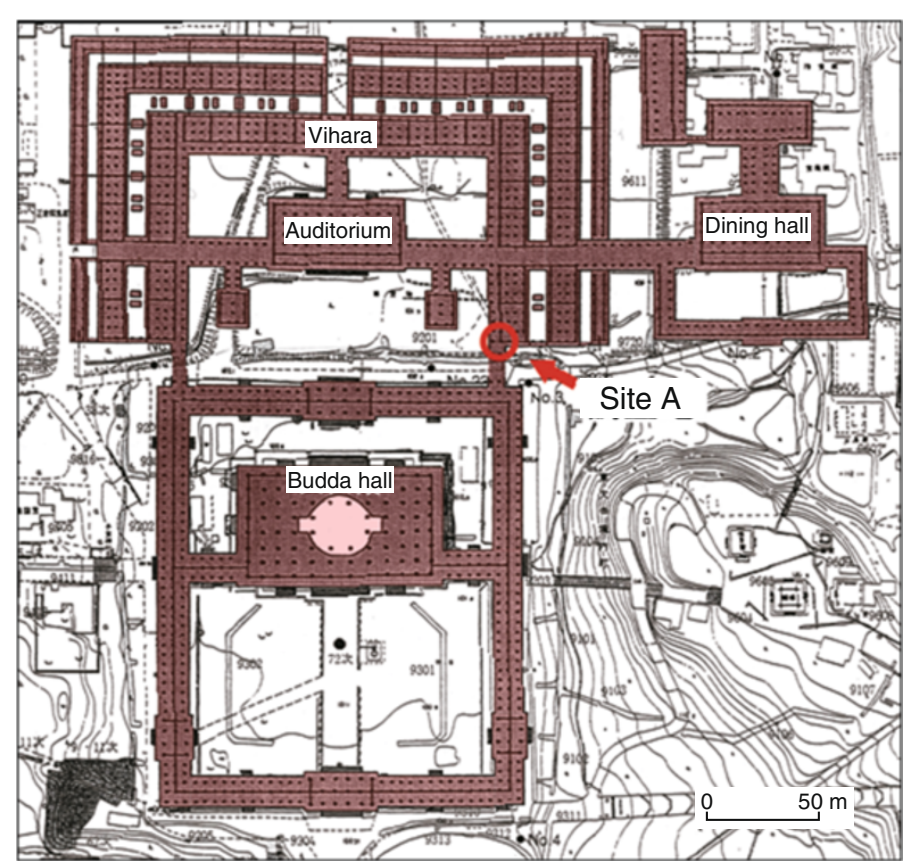

W

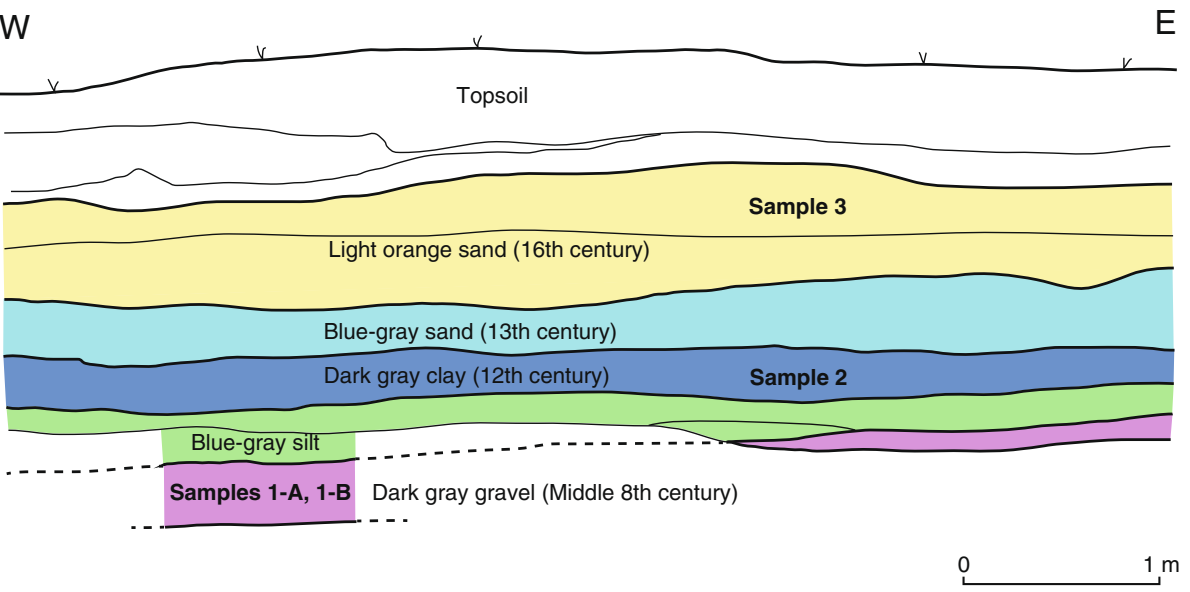

Figure 3 Detailed soil map at Site A and sketch showing exact location and stratigraphic position of samples. Source: Board of Education of Nara City 2011.

in order to evaluate the levels of pollution in the early stages of urban activity: the soil layers here corresponded to the foundation of Ancient Nara in the early eighth century, and iron blacksmiths are considered to have operated around the corner in the early eighth century (Nara National Research Institute for Cultural Properties 2012a, b; personal communication, Dr. Jinno). Samples 203, 204, 205, 206, and 207 were from the early eighth century. Sample 210 dated from a rice paddy in the 9th to 11th centuries.

Site D was located approximately $5 \mathrm{~km}$ south of the center of Ancient Nara (Archaeological Institute of Kashihara 2012a, b). Ten soil samples were collected from a ditch along Suzaku Boulevard, which was an extension of the central avenue, supervised by Dr. Kinoshita and other archeologists working for the Archaeological Institute of Kashihara in Nara Prefecture. Three of these samples were selected for the analysis of sewage and to determine the level of background pollution in the ancient city. The samples consisted of muddy soils from the early to late eighth century (Figure 4) (Archaeological Institute of Kashihara 2012a, b).

The Naganobori mine in Yamaguchi Prefecture in western Honshu is a skarn-type deposit that produced mainly $\mathrm{Cu}$ and $\mathrm{Pb}$. The ore is a contact deposit between Paleozoic Akiyoshi-dai limestone and granite porphyry. The mine had been used since the late seventh century and is known to have supplied almost all of the $\mathrm{Cu}$ used in the construction of the Nara Daibutsu (Mitochou Compilation Committee 2004). The Naganobori mine was 


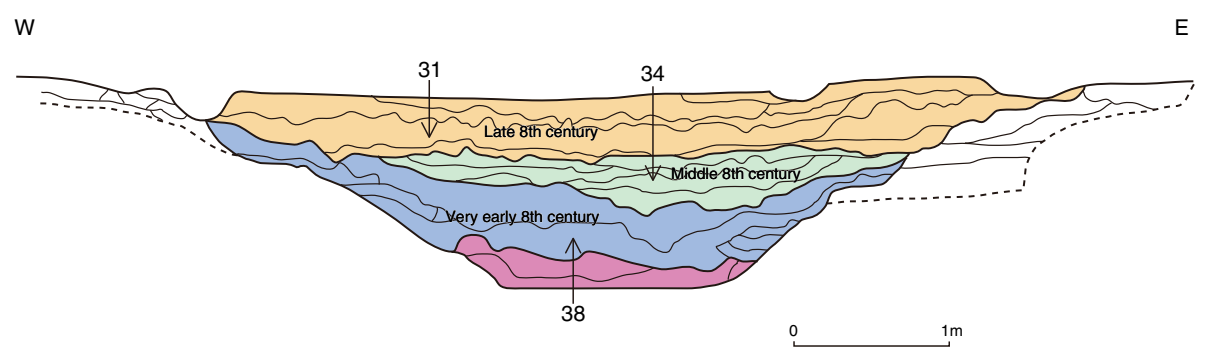

Figure 4 Sketch showing exact location and stratigraphic position of samples at Site D. Source: Archaeological Institute of Kashihara, 2012a, b.

called Nara-nobori mine in seventh century because 'Nara-nobori' means ' $\mathrm{Cu}$ was transported up to the capital city of Nara'.

\section{Analytical procedures Elemental analysis}

Each sample was crushed into fine powder and separated into subsamples for elemental analysis. A $200 \mathrm{mg}$ aliquot of each dry bulk sample was digested in an ultrapure mixture of $\mathrm{HF}$ and $\mathrm{HNO}_{3}$, and any organic residue was removed by filtration. The solutions were then diluted to $100 \mathrm{ml}$ with ultrapure (Milli-Q) water and then subjected to analysis at the Geological Survey of Japan. $\mathrm{Fe}, \mathrm{Co}$, and $\mathrm{Ni}$ were analyzed by inductively coupled plasma atomic emission spectrometry (ICP-AES: Seiko Instruments SPS7800, Chiba, Japan). $\mathrm{Cu}, \mathrm{Pb}, \mathrm{Mn}$, and Zn were analyzed using inductively coupled plasma mass spectrometry (ICP-MS: Agilent 4500 UCO-MS, Tokyo, Japan). $\mathrm{Hg}$ was analyzed using vapor atomic absorption spectrometry (AAS: Japan Instruments Mercury/MA-2000, Tokyo, Japan). A reference rock standard (JSO-1, Geological Survey of Japan) was used to calibrate samples as well as standard solutions prepared from pure elemental standard solutions (Wako Pure Chemical Industry Ltd., Osaka, Japan). Analytical error was estimated to be less than 10\% for each elemental analysis (Kawahata et al. 2006), which is considered to be smaller than the variation attributed to ubiquity in soil.

\section{$\mathrm{Pb}$ isotope analysis}

The digested samples were dried and dissolved in $0.5 \mathrm{M}$ $\mathrm{HBr}$. Two slag samples and chrysocolla from the Naganobori mine were also prepared after decomposition by $\mathrm{HF}_{-} \mathrm{HNO}_{3}$. $\mathrm{Pb}$ was then purified using $0.5 \mathrm{ml}$ anion exchange resin (Bio-Rad AG 1-X8). Other elements were eluted using $3.0 \mathrm{ml}$ of $0.5 \mathrm{M} \mathrm{HBr}$, and the $\mathrm{Pb}$ fraction was collected using $4.0 \mathrm{ml}$ of $6 \mathrm{M} \mathrm{HCl}$. The procedural $\mathrm{Pb}$ blank was $50 \mathrm{pg}$ during chemical separation, which was negligible compared with the sample values of $>1,200 \mathrm{ng}$ $\mathrm{Pb}$. $\mathrm{Pb}$ isotopic ratios were determined at the Geological Survey of Japan using MC-ICP-MS (NEPTUNE multicollector ICP-MS, Thermo Finnigan, Germany) with a Tl doping technique. Samples were diluted to approximately 200 ppb. Pb based upon previous determinations. In addition to four $\mathrm{Pb}$ isotopes $\left({ }^{204} \mathrm{~Pb},{ }^{206} \mathrm{~Pb},{ }^{207} \mathrm{~Pb}\right.$ and $\left.{ }^{208} \mathrm{~Pb}\right),{ }^{202} \mathrm{Hg}$ was also measured to subtract the ${ }^{204} \mathrm{Hg}$ signal from ${ }^{204} \mathrm{~Pb}$. A sample-standard bracketing method was used to correct for instrumental mass bias, using a $\mathrm{Pb}$ standard solution prepared from a reference standard (SRM 981, National Institute of Standards and Technology, Gaithersburg, MD, USA). For comparison, a $\mathrm{Pb}$ solution prepared from another reference standard (SRM 982, National Institute of Standards and Technology, USA) was also analyzed. The mean ${ }^{206} \mathrm{~Pb} /{ }^{204} \mathrm{~Pb},{ }^{207} \mathrm{~Pb} /{ }^{204} \mathrm{~Pb}$, and ${ }^{208} \mathrm{~Pb} /{ }^{204} \mathrm{~Pb}$ values of NIST SRM981 $(n=34)$ were $16.9315 \pm 0.0025,15.4847 \pm 0.0031$, and 36.6772 \pm 0.0079 , respectively (mean \pm 2 standard deviations).

\section{Discussion and evaluation}

The results of metal and $\mathrm{Pb}$ isotope analyses for each of the soil samples are given in Table 1 . Hg content ranged from 39 to $521 \mathrm{ppb}$, with a mean of $160 \mathrm{ppb}$. The two lowest values, 39 and $45 \mathrm{ppb}$, might reflect the background $\mathrm{Hg}$ level in Ancient Nara because the corresponding samples (samples 203 and 38) date to the late seventh century or early eighth century (Figure 5). Samples 204, 205, 206, and 207, which also had relatively low $\mathrm{Hg}$ contents (59 to $92 \mathrm{ppb}$ ), date to the early and

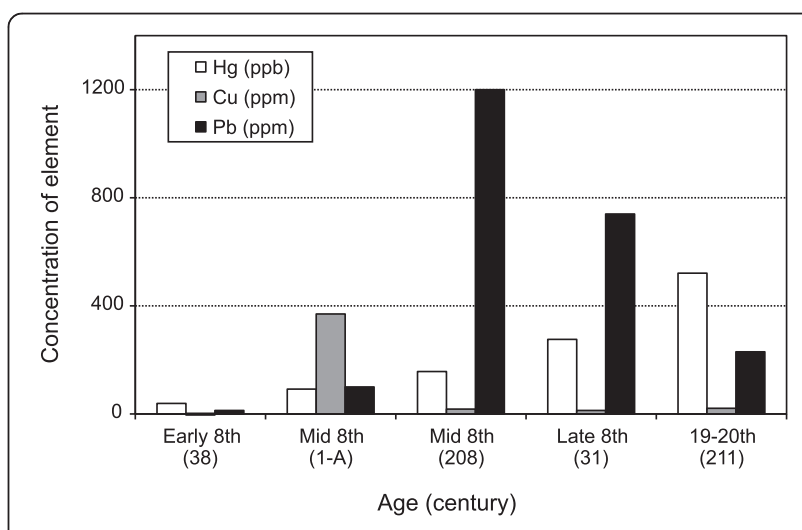

Figure $5 \mathrm{Hg}, \mathrm{Cu}$, and $\mathrm{Pb}$ contents in samples 211, 208, 38, 31, and 1-A. 
middle eighth century. Samples 1-A and 1-B had low $\mathrm{Hg}$ contents (66 and $92 \mathrm{ppb}$, respectively); these samples were obtained from heaps of soil produced during the construction of the Nara Daibutsu and, therefore, date from just before the mercury-gold gilding of the statue was undertaken. Conversely, samples 2, 3, and 210, which are younger than that of the ninth century, had $\mathrm{Hg}$ contents of at least $200 \mathrm{ppb}$. The maximum value of $521 \mathrm{ppb}$ was observed in sample 211, which dates from between 1870 and 1960 and is, thus, probably due to modern contamination. Large amounts of $\mathrm{Hg}$ were released into the environment in the 19th and 20th centuries due to the operation of coal-fired power plants and the use of $\mathrm{Hg}$ in electric lights, batteries, electrodes for sodium hydroxide production, and wood preservation (Japan Oil, Gas and Metals National Corporation 2010).

$\mathrm{Cu}$ levels varied from 2.3 to $370 \mathrm{ppm}$, with a mean of $37 \mathrm{ppm}$. Samples from the early eighth century showed that the background level of $\mathrm{Cu}$ was around $5 \mathrm{ppm}$. The highest values $(>50 \mathrm{ppm})$ were observed in the samples from Site A, which was contaminated by copper slag that splashed out of the blast furnaces when the Nara Daibutsu was cast.

$\mathrm{Pb}$ content varied markedly, ranging between 13 and $1,200 \mathrm{ppm}$. The highest $\mathrm{Pb}$ levels (>1,000 ppm) were observed in samples 208 and 204, which came from an ironsmith dump site dating from the early-middle eighth century. Samples 34 and 31 from a ditch running along the central avenue also had high $\mathrm{Pb}$ contents (700 to $900 \mathrm{ppm}$ ). Interestingly, the mean level of $\mathrm{Pb}$ in Ancient Nara (330 ppm) was considerably higher than the geochemical background level of $30 \mathrm{ppm}$ around the modern city of Nara.

The levels of $\mathrm{Fe}, \mathrm{Mn}, \mathrm{Co}, \mathrm{Ni}$, and $\mathrm{Zn}$ in the soil were all rather low and fell within the ranges observed in modern natural soils in Japan (Imai et al. 2004). Specifically, Fe, $\mathrm{Mn}, \mathrm{Co}, \mathrm{Ni}$, and $\mathrm{Zn}$ ranged between 5,800 to $61,000 \mathrm{ppm}$ (mean 26,300 ppm), 92 to 2,300 ppm (mean $425 \mathrm{ppm}$ ), 4.8 to $32 \mathrm{ppm}$ (mean $14 \mathrm{ppm}$ ), <29 ppm, and 20 to $140 \mathrm{ppm}$ (mean $50 \mathrm{ppm}$ ), respectively. The contents of the latter four metals were all correlated with the content of Fe, suggesting that these five elements are present in the same clay minerals and other soil materials.

$\mathrm{Pb}$ isotope ratios were relatively similar among all the soil samples studied: ${ }^{207} \mathrm{~Pb} /{ }^{206} \mathrm{~Pb}$ ranged from 0.850 to 0.851 and ${ }^{208} \mathrm{~Pb} /{ }^{206} \mathrm{~Pb}$ ranged from 2.093 to 2.094 . The $\mathrm{Pb}$ isotope compositions of the samples from the Naganobori mine $\left({ }^{207} \mathrm{~Pb} /{ }^{206} \mathrm{~Pb}=0.846\right.$ to 0.847 and ${ }^{208} \mathrm{~Pb} /{ }^{206} \mathrm{~Pb}=2.091$ to 2.092$)$ were consistent with a previous study $\left({ }^{207} \mathrm{~Pb} /{ }^{206} \mathrm{~Pb}=0.848\right.$ and ${ }^{208} \mathrm{~Pb} /{ }^{206} \mathrm{~Pb}=2.091$ to 2.092; Saito et al. 2002).

\section{Metal pollution resulting from construction of the Nara Daibutsu}

The level of $\mathrm{Hg}$ pollution can be estimated if the size of the area over which the pollution occurred is known.
Heijoyo in the Nara Basin measures about $5 \mathrm{~km}$ by 5 to $7 \mathrm{~km}$ and the soil layers in the basin are typically several centimeters to $20 \mathrm{~cm}$ thick (Figure 4). Consequently, if $820 \mathrm{~kg}$ of $\mathrm{Hg}$ was uniformly distributed in 5 or $10 \mathrm{~cm}$ thick soil layers (density $1.0 \mathrm{~g} \mathrm{~cm}^{-3}$ ) in a circular area with a $3 \mathrm{~km}$ radius in the Nara Basin, then the $\mathrm{Hg}$ concentration would have been approximately 600 or 300 ppb, respectively. The results of this study suggest that the $\mathrm{Hg}$ content in ancient soil in the middle and late eighth century (around $100 \mathrm{ppb}$ ) was not that high (Table 1). Even samples from the twelfth to eighteenth centuries that were collected in the district adjacent to the Nara Daibutsu had $\mathrm{Hg}$ levels of 200 to $300 \mathrm{ppb}$. Similar Hg contents were observed in the eighth century soil samples 100 and $106 \mathrm{col}-$ lected in the palace grounds of Ancient Nara. The other samples had relatively low $\mathrm{Hg}$ contents. Assuming that the background level in this area was approximately 50 ppb before construction of the Nara Daibutsu, as estimated above, it appears that although $\mathrm{Hg}$ levels increased considerably when the statue was constructed, Ancient Nara was not severely polluted.

There are two possible reasons that might explain the discrepancy between the estimated and measured values: (1) $\mathrm{Hg}$, which is volatile, may have evaporated from the soil (Pirrone et al. 2001), (2) Hg might have been transported to other areas over time. Regarding the second possibility, the district to the north of Nara Daibutsu is currently flat but it was a hollow depression between the eighth to the sixteenth centuries when it would have received debris and soils from fires that burned the wooden structures housing the Nara Daibutsu in 1180 A.D. and 1567 A.D. Nonetheless, samples collected from this area, i.e., samples 1 (middle eighth century), 2 (twelfth century), and 3 (sixteenth century), had relatively low $\mathrm{Hg}$ contents, implying that $\mathrm{Hg}$ transfer was not a main factor.

The soil in Ancient Nara had low Hg levels during the early eighth century; however, these levels more than doubled after the middle eighth century, possibly due to pollution from the construction of the Nara Daibutsu. In addition, there may have been other pollution sources, as a single point source of pollution would not explain the observed increase in background $\mathrm{Hg}$ levels after the mid-Nara era. It is well known that cinnabar has been used for a spell and/or preservative agent for more than 2,000 years (Naruse 1991; Mitochou Compilation Committee 2004), but it was relatively expensive and would likely have been used to a limited extent.

Regarding the evaporation of $\mathrm{Hg}$, the vapor pressure of $\mathrm{Hg}$ is $0.23 \mathrm{~Pa}$ at $25^{\circ} \mathrm{C}$. If the $\mathrm{Hg}$ vapor behaves as an ideal gas, then we can calculate the concentration of $\mathrm{Hg}$ $(C$, in moles per mole of atmosphere) in the atmosphere using the following equation:

$$
0.23 \mathrm{~Pa} /\left(101 \times 10^{3} \mathrm{~Pa}\right)=C /(1+C)
$$


where $C$ is $2.3 \times 10^{-6}$ mole, which is more than 100 times the upper limit of the modern environmental standard in Japan, $0.02 \mathrm{ppm}$. As the molar mass of $\mathrm{Hg}$ is $220.59 \mathrm{~g} \mathrm{~mol}^{-1}, 4.55 \times 10^{-4} \mathrm{~g}$ of $\mathrm{Hg}$ exists in 1 mole of atmosphere, suggesting that the inside of the Great Buddha Hall was severely polluted when gilding was undertaken and that, afterward, an appreciable amount of $\mathrm{Hg}$ continuously and, rather rapidly, evaporated from the soil into the atmosphere. Indeed, this evaporation would explain why less than half of the total amount of $\mathrm{Hg}$ used in the construction of the Nara Daibutsu was present in the soil, even as soon as the middle and late Nara period. These lines of evidence suggest that a limited area around the Great Buddha may have been severely polluted during the gilding, but that Ancient Nara was only moderately polluted with $\mathrm{Hg}$ since the eighth century, probably due to the construction of the Nara Daibutsu as well as the use of cinnabar in the region. The evidence does not support the hypothesis that severe $\mathrm{Hg}$ pollution forced the capital to be relocated from Nara to Kyoto.

High $\mathrm{Cu}$ contents were observed in samples 1, 2, and 3, which contained copper slag from the construction of the Nara Daibutsu. The highest level observed (355 ppm) is well above the upper limit of existing Japanese regulations (125 ppm). Conversely, samples from the other sites had relatively little $\mathrm{Cu}$, and background levels were probably a few parts per million. The higher levels observed in some of the samples (i.e. $>10 \mathrm{ppm}$ ) may have been due to the widespread use of $\mathrm{Cu}$ in mirrors, coins, bronze statues, and arms at the time. A more likely explanation for the presence of the grassland (instead of a forest) at Wakakusa Hill was not because of pollution, but rather because the field was burned every year as part of a New Year celebration.

In summary, our results suggest that $\mathrm{Hg}$ and $\mathrm{Cu}$ pollution accompanying the construction of the Nara Daibutsu only had a limited influence on the environment.

\section{$\mathrm{Pb}$ pollution in Ancient Nara}

Analysis of soils from Ancient Nara suggests that traces of ancient human activity are indeed evident in the environment. Both the extent of the contamination and the nature of the contaminants are generally consistent with the features of human activity in Ancient Nara. The contamination in samples 31 and 34 from the ancient ditch is considered to be due to urban pollution. According to historical documents, the ditch was quite dirty and contained the remains of humans, cattle, and horses, suggesting that people may have indiscriminately disposed of waste in these ditches (Archaeological Institute of Kashihara 2012a, b). Further, although water from the Saho River was diverted into the ditch, it was too weak to flush out the sewage efficiently (Figure 1). $\mathrm{Hg}, \mathrm{Pb}, \mathrm{Fe}$, and $\mathrm{Cu}$ were also materials that were in common use in the Nara period. $\mathrm{Hg}$ and $\mathrm{Pb}$ were used for pigments, enamel, and/or lead glass; $\mathrm{Cu}$ and $\mathrm{Sn}$ were used for producing bronze coins and statues. Malachite is a copper carbonate hydroxide mineral which was used as a green pigment and Fe oxide (hematite) was used as a red pigment (Kitano 2013).

Comparing the $\mathrm{Hg}, \mathrm{Cu}$, and $\mathrm{Pb}$ contents of Ancient Nara to modern standards reveals that only $\mathrm{Pb}$ (over $330 \mathrm{ppm}$ ) exceeded modern levels (15 ppm for $\mathrm{Hg}$, $125 \mathrm{ppm}$ for $\mathrm{Cu}$, and $150 \mathrm{ppm}$ for $\mathrm{Pb}$ ). The particularly high contents observed in samples 208 and 204 could be related to the high $\mathrm{Pb}$ content at site $\mathrm{C}$. Indeed, the observed level of $\mathrm{Pb}$ contamination is considered harmful for human health. For example, if you inhaled $150 \mathrm{mg}$ of soil per day that was contaminated with $200 \mathrm{ppm}$ of $\mathrm{Pb}$, and if the absorption efficiency was $40 \%$, then $100 \mathrm{mg}$ of $\mathrm{Pb}$ would accumulate in your body over a 20-year period and potentially cause lead poisoning (Yamada 1977). Thus, although it has been postulated that people living near blacksmiths in Ancient Nara may have suffered from lead poisoning, these smiths employed mainly iron, which means that it was unlikely that they were responsible for the lead contamination in the soil. However, further investigation is needed to determine whether $\mathrm{Pb}$ contamination was observed throughout the city.

The various isotopes of $\mathrm{Pb}$ provide an ideal tool for characterizing the original source of heavy metal pollution because the isotopic ratios are not measurably influenced by physical or chemical fractionation processes. Thus, when the ${ }^{207} \mathrm{~Pb} /{ }^{206} \mathrm{~Pb}$ and ${ }^{208} \mathrm{~Pb} /{ }^{206} \mathrm{~Pb}$ ratios of the Ancient Nara soil samples were compared to the ratios observed in various foreign artifacts (mirrors and swords from China and Korea) or in samples from various Japanese mines, the results show that the most plausible origin of the $\mathrm{Pb}$ in Ancient Nara was the Naganobori mine. Figure 6 shows that when the $\mathrm{Pb}$ isotope ratios of the soil samples were plotted against those of the Naganobori mine, the curves were similar. This mine was thus undoubtedly the source of $\mathrm{Cu}$ for the production of the Nara Daibutsu. Indeed, this dependence on the mine is documented in historical records, namely, on narrow strips of wood upon which official messages were written during the Nara Period (Mitochou Compilation Committee 2004): this is also evidenced by the higher relative abundance of $\mathrm{Ag}$ and As (Hatanaka 2003). This study reconfirmed that the $\mathrm{Pb}$ isotope ratios in sample 1-A, which contained drops of copper from the construction of the Nara Daibutsu, were similar to those in samples obtained from the Naganobori mine. In addition, the $\mathrm{Pb}$ isotopic value is the same as that in all the other solid samples in Ancient Nara. We therefore conclude that all of the $\mathrm{Pb}$ contamination in Ancient Nara originated from the Naganobori mine. The extraction of ore at Naganobori contributed considerably to the production of the Nara Daibutsu. However, the mining 


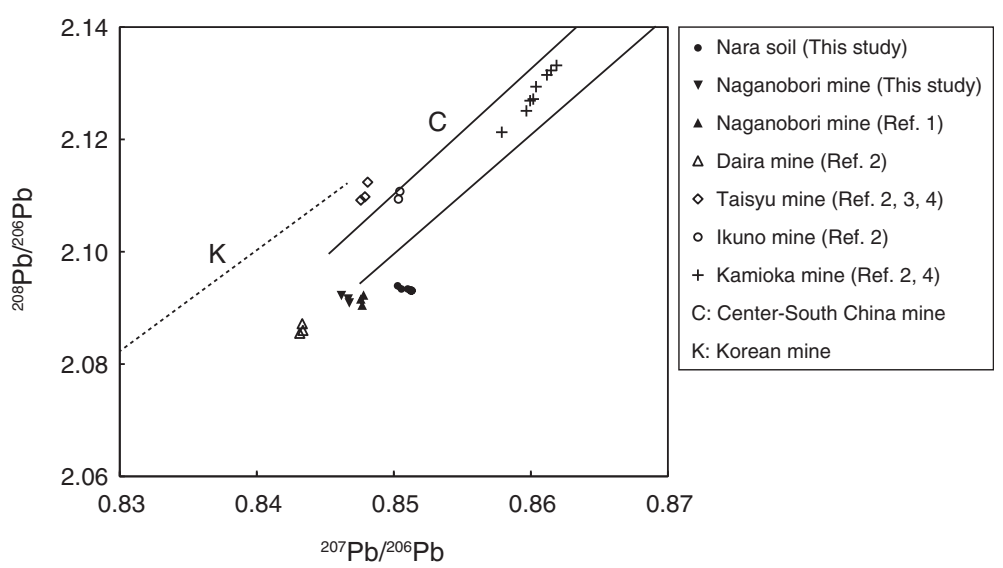

Figure $6 \mathrm{~Pb}$ isotopic ratios $\left({ }^{208} \mathrm{~Pb} /{ }^{206} \mathrm{~Pb}\right.$ versus ${ }^{207} \mathrm{~Pb} /{ }^{206} \mathrm{~Pb}$ ) in Ancient Nara soil samples and reference ore deposits. $\mathrm{C}$ (area between solid lines) represents bronze mirrors brought from China during the Eastern Han Dynasty and the Three Kingdoms era (25 to $280 \mathrm{~A} . \mathrm{D}$.) with Pb originating from central to southern China; $\mathrm{K}$ (dashed line) represents a bronze mirror and swords brought from the Korean Peninsula during the Yayoi era (10 B.C. to 3 A.D.) with Pb originating from the Korean Peninsula (Saito et al. 2002). Data from (1) Saito et al. 2002; (2) Sasaki et al. 1982; (3) Mabuchi and Hirao 1982; and (4) Mabuchi and Hirao 1987.

activity associated with the construction of the Nara Daibutsu may also have generated $\mathrm{Pb}$ pollution in the capital city, even in ancient times.

Although it is currently difficult to identify the exact source of $\mathrm{Pb}$ contamination, several possible sources exist. A number of studies on $\mathrm{Pb}$ isotopes have examined bronze coins (Mabuchi et al. 1982; Saito 2001a; Saito et al. 2002). However, it is considered unlikely that these coins would have increased the $\mathrm{Pb}$ content of environmental samples, such as the soils in urban areas because of distribution amount. Based on an analysis of the inorganic pigments used to decorate treasures at Shosoin, the Imperial Repository constructed to prevent damage arising from the humid Japanese climate, leadbased pigments may have been relatively popular (Naruse 2004). Although it was reported that lead carbonate (lead white) was not produced in Japan and that it was imported from China during the Nara era (Winter 1981), lead chloride produced in Japan was widely used for white paint (Naruse 1992; Winter and Emile 1988). According to a production report from a government-run workshop of Buddhist sculptors during the Nara Period in 734 A.D., red lead was made from metallic lead in order to produce lead glass (Naruse 1991). Lead isotope analysis of tricolored glaze dating from the Nara Period showed that the $\mathrm{Pb}$ isotopic composition was comparable to that from the Naganobori mine (Saito 2001b). Further study is required to understand the extent of environmental pollution in this ancient civilization.

\section{Implications of pollution in the ancient city}

During the seventh and eighth centuries, many religious structures, such as temples and statues, as well as tumuli, were constructed in Japan. The material requirements of large bronze statues were considerable, as exemplified by the Nara Daibutsu; and the tumuli of the previous era were associated with large numbers of terra-cotta figures, whose firing required large quantities of wood fuel. Relocations of the capital city were also frequent and entailed extensive utilization of wood resources for the construction of new buildings.

The end of the burial tradition and the beginning of the Buddhist practice of cremation occurred in the eighth century. The first person to be officially cremated in Japan was the Buddhist priest Dosho in 700 A.D., and the first emperor to be cremated was Jito in 702 A.D. According to historical records, the government recommended restraint regarding the construction of large tumuli in the seventh century (personal communication, Dr. Kinoshita). After the relocation of the capital to Ancient Kyoto in 794 A.D., no more large bronze statues were built around Nara and Kyoto. Japanese society had already started to shift away from mass consumption to a more sustainable system during the Nara period.

\section{Conclusions}

We investigated metal pollution in the eighth century city of Ancient Nara, the first large and international city in Japan. We found that the pollution arose due to urban activity and the construction of the Nara Daibutsu and concluded the following:

1) Urban activity increased the levels of $\mathrm{Hg}, \mathrm{Cu}$, and $\mathrm{Pb}$ in soils.

2) $\mathrm{Hg}$ and $\mathrm{Cu}$ pollution accompanied the construction of the Nara Daibutsu, but the influence of this pollution was limited to a section of the city. 
3) At several sites, the soil was polluted with enough $\mathrm{Pb}$ to harm human health, with some of these values exceeding modern Japanese safety standards. The isotopic composition of $\mathrm{Pb}$ in these soils indicated that it originated mainly from the Naganobori mine. The mine made a major contribution to the founding of the Nara Daibutsu and was a source of some of the observed lead pollution.

\section{Competing interests}

The authors of this manuscript declare that they have no competing interests.

\section{Authors' contributions}

HK proposed the topic and conceived and designed the study. SY, KY, and HK collected samples for the study. SY, KY, TO, GS, and MI contributed to the chemical and isotope analysis. All authors read and approved the final manuscript.

\section{Authors' information}

HK is a Professor at the Atmosphere and Ocean Research Institute, The University of Tokyo. He has focused on geochemical studies for the last 30 years and has published approximately 200 papers in international journals. He has received more than 3,000 citations. SY was a undergraduate course student at the laboratory of HK. KY, TO, GS, and Ml are also geochemists with considerable experience in chemical and isotope analysis.

\section{Acknowledgements}

We sincerely thank Dr. A. Watanabe and Dr. M. Jinno at the Nara National Research Institute for Cultural Properties, Dr. F. Sugaya, Dr. K. Saito, Dr. W. Kinoshita, and Dr. T. Fukunishi at Archaeological Institute of Kashihara, Nara Prefecture, Mr. M. Kanekata and Mr. T. Yasui at the Buried Cultural Property Investigation Center of Nara, and Mr. Y. Ikeda at the Culture Exchange Hall of Naganobori Mining for providing archeological soil samples and related data for this study. We also acknowledge Prof. K. Takemura and Dr. Y. Shitaoka of the Institute for Geothermal Sciences, Kyoto University for the instruction of archeological studies. Also, we would like to express our sincere appreciation to two anonymous reviewers for improvements to the manuscript. This study was supported by a grant-in-aid for scientific research, 22224009 (H. Kawahata), from the Japan Society for the Promotion of Science. This paper presents quantitative data on $\mathrm{Pb}$ isotopes and toxic metals in samples of ancient soil and remains collected from archeological sites in Ancient Nara in order to evaluate the effect of urban activity on ancient metal pollution. Although it has been proposed that pollution resulting from urban activities (especially construction of the Nara Daibutsu) was responsible for the end of Ancient Nara and relocation of the capital, no scientific verification has been conducted to date. The Great Buddha statue is the largest bronze statue in the world and is a registered UNESCO World Heritage site, and it is well known among Japanese and foreign tourists. Therefore, the heavy metal pollution would hopefully receive much attention. This research has important implications for building a sustainable society in the future.

\section{Author details}

${ }^{1}$ Atmosphere and Ocean Research Institute, The University of Tokyo, Kashiwanoha 5-1-5, Kashiwa, Chiba 277-8564, Japan. ${ }^{2}$ Department of Earth and Planetary Science, Faculty of Science, The University of Tokyo, Hongo 7-3-1, Bunkyo-ku, Tokyo 113-0033, Japan. ${ }^{3}$ Geological Survey of Japan, National Institute of Advanced Industrial Science and Technology (AIST), Higashi 1-1-1, Tsukuba, Ibaraki 305-8567, Japan.

\section{Received: 25 October 2013 Accepted: 11 June 2014}

\section{Published: 3 July 2014}

\section{References}

Archaeological Institute of Kashihara (2012a) Hachijo North ruins. In: Archaeological Report, Archaeological Institute of Kashihara. Nara Prefecture, Nara, pp 73-94
Archaeological Institute of Kashihara (2012b) Hachijo North ruins. In: Reference document for information session at Hachijo North ruins. Archaeological Institute of Kashihara, Nara Prefecture, Nara, pp 1-4

Board of Education of Nara City (2011) Archinological survey of the district to the north of the Nara Daibutsu - sites of historical importance near Todaiji Temple. 1-3., Board of Education of Nara City Report in December, Nara City (in Japanese)

Hall JW (1993) The Cambridge history of Japan. Ancient Japan, vol. 2. Cambridge University Press, Cambridge, p 650

Hatanaka A (2003) Discussion of copper produced at Naganobori written on mokkan. Mokkann Gakkai 25:1-30 (in Japanese)

Imai N, Terashima S, Ohta A, Mikoshiba M, Okai T, Tachibana Y, Togashi S, Matsuhisa Y, Kanai Y, Kamioka H, Taniguchi M (2004) Geochemical map of Japan. In: Geological Survey of Japan., https://gbank.gsj.jp/geochemmap/ index_e.htm. Accessed 6 Jun 2014

Ishino T (2004) Production of Nara Daibutsu. Komine Publishing Company, Tokyo (in Japanese)

Japan Broadcasting Corporation (2012) Nara and Asuka eras. In: Japanese history. NHK, Tokyo, p 128

Japan Oil, Gas and Metals National Corporation (2010) Rare metal handbook. Kinzoku-Jihyo, Tokyo

Kawahata H, Nohara M, Aoki K, Minoshima K, Gupta LP (2006) Biogenic and abiogenic sedimentation in the northern East China Sea in response to sea-level change during the Late Pleistocene. Glob Planet Change 53:108-121

Kitano N (2013) Traditional view on Bengara pigment (Hematite, a-Fe[2]O[3]) coating on wooden architectures in Japan. Yuzankaku, Tokyo

Kito H (2000) Jinkou kara yomu Nihon no rekishi (History of Japan based on the Population). Kodansya Ltd., Tokyo (in Japanese)

Konishi M (2002) Estimation of $\mathrm{Au}$ and $\mathrm{Hg}$ on the construction of the Nara Daibutsu in the Todaiji Temple. J Hist Metrology 24:91-110 (in Japanese)

Mabuchi H, Hirao Y (1982) Lead isotope ratios in dotaku (bell-like object) excavated in Japan. J Archeological Soc Nippon 68:42-62 (in Japanese)

Mabuchi H, Hirao Y (1987) Lead isotope ratios of lead ores in East Asia. J Archeological Soc Nippon 73:71-82 (in Japanese)

Mabuchi H, Hirao Y, Sato S, Midorikawa N, Igaki K (1982) Lead isotope ratios of ancient East Asian coins. Archaeology Nat Sci 15:23-39

Matsui K (2007) Collapse of Earth's system. Shincho-sensho, Tokyo (in Japanese)

Committee MC (2004) Overview of history of Mitochou Town. Mitochou Town, Yamaguchi, Japan (in Japanese)

Moore R (2011) Metropol Parasol, Seville by Jürgen Mayer H - review. In: Art and design, The Observer, Guardian., http://www.theguardian.com/artanddesign/ 2011/mar/27/metropol-parasol-seville-mayer-review. Accessed 6 Jun 2014

Nara Meteorological Observatory (2014), net.go.jp/nara/kishou/fuken_kishou.htm. Accessed 6 Jun 2014

Nara National Research Institute for Cultural Properties (2010) Summary report of excavations of mokkans at the Heijyokyo Palace, Nara Capital City. Bull Nara National Res Inst Cult Properties 40:1-23 (in Japanese)

Nara National Research Institute for Cultural Properties (2012a) Excavations at the Nara Capital site and at Nara temples, Excavation in Blocks, 1 and 2, East First Ward on Third Street (no. 478, 486, and 488). Bulletin of Nara National Research Institute for Cultural Properties June:190-204 (in Japanese), Nara, Japan

Nara National Research Institute for Cultural Properties (2012b) Press report on the excavation around the Suzaku-mon (main gate) (Heijo-kyo excavation No.495), 1-7 (in Japanese), Nara, Japan

Naruse M (1991) Red seal and red pencil at Shosoin. Japanese Hist Yoshikawa Köbunkan 521:84-89 (in Japanese)

Naruse M (1992) Lead white pigments in the Nara period. Annu Rep Office Shosoin Treasure House 14:33-58 (in Japanese)

Naruse K (2004) Inorganic pigments found on objects in the Shoroin. Bull Office Shosoin Treasure House 26:13-60 (in Japanese)

Ozaki M (2000) Geology of the Nara district. Geological Survey of Japan, Tsukuba

Pirrone N, Costa P, Pacyna JM, Ferrara R (2001) Mercury emissions to the atmosphere from natural and anthropogenic sources in the Mediterranean region. Atmos Env 35:2997-3006

Saito T (2001a) Comprehensive lead isotope analysis of Japanese coins issued in Nara to Yedo periods. Bull National Mus Japanese Hist 86:65-129

Saito T (2001b) Lead isotope analysis of tricolored glaze in Nara period and green glaze in Heian period. Bull National MusJapanese Hist 86:199-208 
Saito T, Takahashi T, Nishikawa Y (2002) Chemical study of ancient coins - lead isotope and metal composition of the Kocho-Junisen., IMES Discussion Paper, No.2002-J-30 (in Japanese)

Sasaki A, Sato K, Cumming GL (1982) Isotopic composition of ore lead from the Japanese islands. Min Geol 32:457-474

Shirasuga K (2002) Pollution by the Nara Daibutsu? J Soc Inorg Mater 9:537-541

Shotyk W, Weiss D, Appleby PG, Cheburkin AK, Frei R, Gloor M, Kramers JD, Reese S, van der Knaap WO (1998) History of atmospheric lead deposition since

$12,370{ }^{14} \mathrm{C}$ yr BP from a peat bog, Jura Mountains, Switzerland. Science 281:1635-1640

Winter J (1981) 'Lead white' in Japanese paintings. Stud Conserv 26:89-101

Winter J, Emile J (1988) 'Lead white' in Japanese paintings II: measurements of lead isotope ratios. Kobunkazai no Kagaku 33:33-44

Yamada N (1977) Lead poisoning at present. Medical Library, Tokyo (in Japanese)

doi:10.1186/2197-4284-1-15

Cite this article as: Kawahata et al:: Heavy metal pollution in Ancient

Nara, Japan, during the eighth century. Progress in Earth and Planetary Science 2014 1:15.

\section{Submit your manuscript to a SpringerOpen ${ }^{\circ}$} journal and benefit from:

- Convenient online submission

- Rigorous peer review

- Immediate publication on acceptance

- Open access: articles freely available online

- High visibility within the field

- Retaining the copyright to your article

Submit your next manuscript at $>$ springeropen.com 